\title{
Corrosion Control in the Desalination Industry
}

\author{
Michael Schorr ${ }^{1}$, Benjamín Valdez ${ }^{1}$, Juan Ocampo ${ }^{2}$ and Amir Eliezer ${ }^{3}$ \\ ${ }^{1}$ Instituto de Ingeniería, Departamento de Materiales, Minerales y Corrosión, Universidad \\ Autónoma de Baja California, México, Blvd. Benito Juárez S/N, CP. 21900, \\ Mexicali, Baja California, \\ ${ }^{2}$ Facultad de Ingeniería Mexicali, Universidad Autónoma de Baja California, \\ México, Blvd. Benito Juárez S/N, CP. 21900, Mexicali, Baja California, \\ ${ }^{3}$ Sami Shamoon College of Engineering Corrosion Research Center, Ber Sheva, \\ 1,2México \\ ${ }^{3}$ Israel
}

\section{Introduction}

The environment quality, worldwide water scarcity and clean energy have been established today as central disciplines in modern science, engineering and technology. They are already being linked to the crucial, actual problems of climate change, global warming and greenhouse-gas emissions, all interrelated phenomena (Valdez \& Schorr, 2010). Innovative desalination technology of saline water (SW) contributes to alleviate these problems by producing abundant fresh water, from SW, mainly seawater and brackish water (I.D.E Technologies, 2004; Charash et al, 1991).

Desalination plants (DPs) have a high level of corrosion risk since they handle and process aggressive SW under severe operating conditions which include filtration, heat exchange, distillation, evaporation, agitation and circulation and high flow velocities, often turbulent. These SW: sea, brackish and brines cause localized corrosion such as pitting, crevice, galvanic and stress corrosion. In addition, biological fouling and mineral scaling are frequent nuisances that alter the equipment surface performance and induce corrosion (Malik, 2000).

Desalination has been practiced since ancient times for providing drinking water on seafaring ships, using solar or fuel heat for distillation. Aristotle, the Greek philosophic scientist (384-322 B.C.) mentions desalting seawater with solar energy. Natural gas was used as fuel in ancient China to evaporate water from salt brine.

Moses, the prophet, wandering through the Sinai Desert found water that the people could not drink because it was bitter. Then, Moses threw a piece of wood into the water and the water become sweet (Exodus 15:22-25). Perhaps, these are some antique practices on water treatment, their details lost through the eons...

Public water supplies are recorded in the Bible: Genesis 26, II Kings 20:20, John 4; community wells and water works where built by the Hebrews, Egyptians, Mesopotamians, Phoenicians, Persians, Greeks and Romans, including canals, aqueducts, reservoirs, distribution pipes and flood-control facilities. 
Desalination is not a new technology; in 1790 the US Government received a proposal to install a distillation method to convert salt water to fresh water. In 1952 the US Congress passed "The Saline Water Act" to provide federal support for desalination, as a new mean for supplementing long deficient supplies of fresh water.

Use of suitable corrosion resistance alloys (CRAs): titanium, stainless steels (SS), Ni-base alloys, $\mathrm{Cu}-\mathrm{Ni}$ alloys and $\mathrm{Al}-\mathrm{Mg}$ alloys is the most direct means of preventing corrosion. Corrosion resistance is the main property to be considered in the choice of materials for plant equipment. Today about 15,000 DPs operate worldwide with an estimated total production capacity of 32 million $\mathrm{m}^{3} /$ day, in the Mediterranean Sea coast countries, the Middle East, South America deserts, the Canary and Caribbean islands; all places with limited water supplies. In the USA there are 1,500 desalination facilities constituting a 30b USD business which is expected to double in capacity by 2016. A limited number of DPs have been built on the California coast, primarily because of desalination cost is generally higher than the cost of other water supply alternatives, however, as drought conditions occurs desalination large projects are being planned, e.g., the Carlsbad project.

The world largest plant in Saudi Arabia produces $1 \mathrm{Mm}^{3} /$ day. An advanced seawater DP was installed in 2005 in Ashkelon, Israel with a capacity of $100 \mathrm{Mm}^{3} /$ year. It is operated by IDE Technologies; uses Seawater Reverse Osmosis (SWRO) technology and employs stateof-the-art means for recovery of energy from independent, combined cycle electricity station, with a capacity of $80 \mathrm{MW}$ (Kronenberg, 2004).

\subsection{Water resources}

There is an almost unfathomable amount of water on earth: about 1.4 billion $\mathrm{km}^{3}$ (330 million cubic miles), (Barlow and Clark, 2002). Of this total, less than 3\% is fresh water (about 35,000,000 $\mathrm{km}^{3}$ ), much of which (about 24,000,000 $\mathrm{km}^{3}$ ) is inaccessible due to the fact that it is frozen in ice caps and glaciers (Figure 1). It is estimated that just $0.77 \%$ (about $11,000,000 \mathrm{~km}^{3}$ ) of all the earth's water is held as groundwater, surface water (in lakes, swamps, rivers, etc.) and in plants and the atmosphere (Shiklomanov, 1993).

\section{The desalination industry}

Due to an increased population growth and the expectation of high living standards, the demand for water and electricity in the desertic and arid regions of the world is soaring. Placing DPs combined with power generating units allows the heat extracted from the process to evaporate seawater. Desalination is the most viable solution to the 21th century's shortage of fresh water for human consumption and irrigation obtained from sources of SW (Kowitt, 2009).

The desalination industry is in the middle of an expansion and modernization program designed to construct more efficient and larger $\mathrm{DP}^{\prime}$, that will reduce production costs. The maintenance of its infrastructure assets requires a robust understanding of the integration between global climate change and the materials engineering-structure-climate-interaction, induced by variations in humidity, temperature, solar radiation, drought and pluvial precipitation mainly during extreme events (Valdez \& Schorr, 2010). Recently the Institute of Materials, Minerals and Mining (IOM3), London has published a special issue of its journal which brings together papers examining climate change induced corrosion (Valdez \& Schorr, editors 2010; Roberge, 2010). 


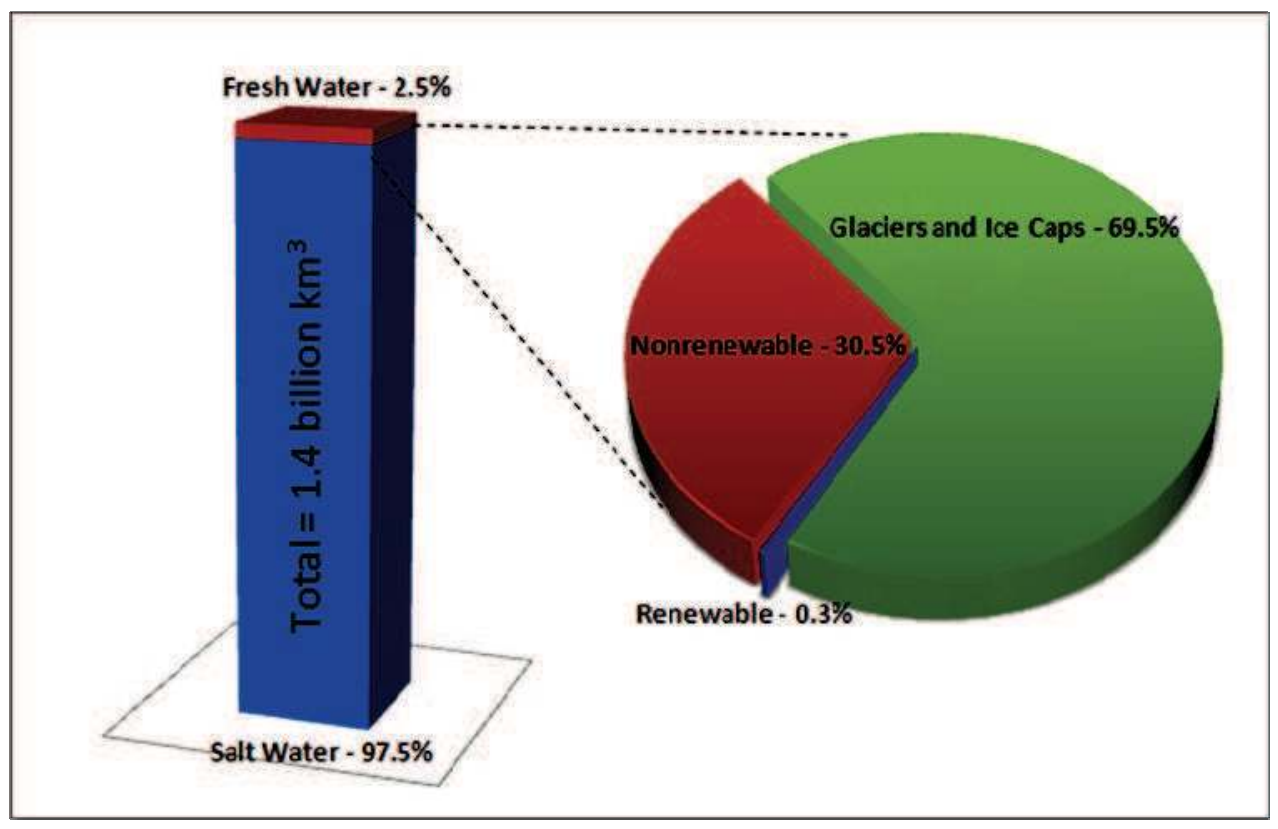

Fig. 1. Distribution of world water

This industry is based on the principles and practices of water chemistry, chemical engineering and efficient energy management. The most widely utilized technologies are thermal and membrane but solar "green" energy is applied, without relying on fossil fuels: oil, gas and coal.

Actual innovation desalination technology is less energy-consuming and more environmentally friendly. $\mathrm{DP}^{\prime}$ s require varied engineering materials, structures, installations, equipment and machinery that should function with industrial efficiency and labor safety to assure its economic performance.

The economic and social relevance of the desalination industry is evident by the activities of the diverse international and national professional associations, R\&D institutions and industrial enterprises involved in all the aspects of desalination science, engineering and technology (Table 1). It includes authorities from government, industry, and academia that address progress of vital importance for the national and global prosperity.

Lately, the threat of bioterrorism, have pushed desalination to the forefront of efforts to preserve the available supply of water.

\section{Desalination processes and plants}

DP's have a high level of corrosion risk since they handle and process aggressive SW under severe operating conditions which include filtration, heat exchange, distillation, evaporation, agitation, and high flow velocities, often turbulent(Dillon, 1994). There is no universal desalination process; every type of SW requires a process adapted to its physicochemical characteristic and performance. The DPs are feed with seawater, containing $35 \mathrm{~g} / 1$ of total dissolved solids (TDS) or brackish water with TDS in the range 2 to $5 \mathrm{~g} / \mathrm{l}$, 


\begin{tabular}{|c|c|c|}
\hline \multicolumn{2}{|l|}{ Association, Organization, Enterprise } & \multirow{2}{*}{$\begin{array}{l}\text { Website } \\
\text { www.idadesal.org }\end{array}$} \\
\hline International Desalination Association & IDA & \\
\hline European Desalination Society & EDS & www.edsoc.com \\
\hline American Desalting Association & ADA & www.webrom.com/ada \\
\hline $\begin{array}{l}\text { Asociación Española de Desalación y } \\
\text { Reutilización }\end{array}$ & AEDyR & www.aedyr.com \\
\hline Middle East Desalination Research Center & MEDRC & www.medrc.org \\
\hline $\begin{array}{l}\text { Office of Water Research and Technology, } \\
\text { USA }\end{array}$ & OWRT & www.ntis.org \\
\hline US Bureau of Reclamation, DOI & USBR & www.usbr.gov/water/desaltin \\
\hline International Atomic Energy Agency & IAEA & \\
\hline Kuwait Institute of Scientific Research & KISR & \\
\hline $\begin{array}{l}\text { UNESCO-IHE Institute for Water } \\
\text { Education, The Netherlands }\end{array}$ & & \\
\hline $\begin{array}{l}\text { Encyclopedia of Desalination and Water } \\
\text { Resources }\end{array}$ & & www.desware.net \\
\hline Israeli Desalination Society & IDS & www.ids.org.il \\
\hline \multicolumn{3}{|c|}{$\begin{array}{l}\text { Bureau for Use of Saline Water, SCT, } \\
\text { Mexico }\end{array}$} \\
\hline Commissariat a l'Energie Atomic & CEA & www.cea.fr \\
\hline Desalination and Water Treatment Lab. & & www.bgm.ai.il \\
\hline Veolia Water Solutions and Technologies & & www.veoliawater.com \\
\hline GE Water and Process Technologies & & www.gewater.com \\
\hline \multicolumn{3}{|l|}{ Siemens Water Technologies } \\
\hline Japan desalination Association JWWA & JWWA & www.k4.dion.ne.jp/ jda-hp21/ \\
\hline IDE Technologies & & www.ide-tech.com \\
\hline \multicolumn{3}{|l|}{ Belsa Agua, Spain } \\
\hline \multicolumn{3}{|l|}{ Doosen, South Korea } \\
\hline \multicolumn{3}{|l|}{ Fisia Italimpianti } \\
\hline Dow Water Solutions & & www.dowwater.com \\
\hline California Coastal Commission & & www.coastal.ca.gov \\
\hline MeKorot National Water Co. & & Mekorot.com.il \\
\hline Hydranautics , CA, USA & & www.membranes.com \\
\hline Desalination Directory Online & & www.desline.com \\
\hline Caribbean Desalination Association & & www.caribda.com \\
\hline Indian Desalination Association InDA & InDA & Magnum.base.esnet \\
\hline
\end{tabular}

Table 1. Associations, organizations and enterprises dealing with desalination science, engineering and technology 
taken from briny wells or wells infiltrated by seawater. Many DP's are located in desertic/arid regions with a harsh climate and limited rainfall. About one-fifth of the DP's operate in the Middle East with Saudi Arabia, producing half of the world desalted water.

Desalination is used to produce potable water from water sources containing dissolved salts, such as sea water or brackish water. Natural waters are classified according to their total dissolved solids (TDS) values (Table 2):

\begin{tabular}{|l|l|}
\hline \multicolumn{1}{|c|}{ Type of water } & \multicolumn{1}{c|}{ TDS value $(\mathrm{mg} / \mathrm{l})$} \\
\hline Sweet water & $0-1000$ \\
\hline Brackish waters & $1000-5000$ \\
\hline Moderately saline water & $5000-10000$ \\
\hline Severely saline water & $10000-30000$ \\
\hline Seawater & More than 30000 \\
\hline
\end{tabular}

Table 2. Natural water classification

The main application of desalination techniques is the production of fresh water on ships, islands, and in the coastal regions of arid Middle East countries. The water obtained is so pure that consumers do not like the lack of taste; therefore small quantities of salt water are then added to improve the flavour. Two main desalination technologies (membrane and thermal) are implemented worldwide (Table 3).

\begin{tabular}{|l|l|}
\hline \multicolumn{1}{|c|}{ Process } & \multicolumn{1}{c|}{ Characteristics } \\
\hline a. $\begin{array}{l}\text { Membrane Reverse } \\
\text { Osmosis RO }\end{array}$ & $\begin{array}{l}\text { Pressure is applied to the SW forcing it trough a } \\
\text { semipermeable plastic membrane that separates brine } \\
\text { from water. }\end{array}$ \\
\hline b. $\quad \begin{array}{l}\text { Thermal Multistage } \\
\text { Flash Distillation MFD }\end{array}$ & $\begin{array}{l}\text { SW is heated and the pressure is lowered in several } \\
\text { stages so the water flashes into steam, to be cooled. } \\
\text { Low pressure steam, } 60^{\circ} \mathrm{C} \text { is handled in a train of } \\
\text { evaporative-condensers (effects) with heat rejection } \\
\text { condensers. } \\
\text { Dultieffect Distillation MED } \\
\text { Mechanical Vapour } \\
\text { Compression MVC }\end{array}$
\end{tabular}

Table 3. Membrane and thermal desalination processes

- Membrane separation process e.g. Reverse Osmosis (RO). Under high pressure the water molecules contained in seawater pass through a selective membrane while the dissolved salt ions do not pass through the membrane. (Figure 2), Some RO membranes are made from high-grade polymeric PVDF material to form a hollow fiber membrane that is very durable and less prone to breakage. Special membrane incorporate a brush layer of hydrophilic polymer chain anchored to the membrane surface which blocks foulants such as bacteria, mineral crystal and protein from adhering to the membrane. It also resists mineral scaling by preventing its nucleating on the surface. Others membranes are made from polymers specially developed and manufactured to serve in $\mathrm{DP}^{\prime}$ s. $\mathrm{RO}$ desalting devices are used also to upgrade the quality of industrial water. 
- The thermal processes are based on improved distillation, evaporation and condensation technologies with the aim to save energy and to obtain fresh water with a low level of TDS and at a low cost operation. In general, the thermal processes are more expensive than $\mathrm{RO}$ but distillation produces pure water independent of the quality and salinity of the feed water. The cost of desalting brackish ground water is generally less than the cost of desalting seawater due to a lower TDS content. The average expense for desalting brackish water is $0.50 \mathrm{USD} / \mathrm{m}^{3}$ and for seawater $1.5 \mathrm{USD} / \mathrm{m}^{3}$.

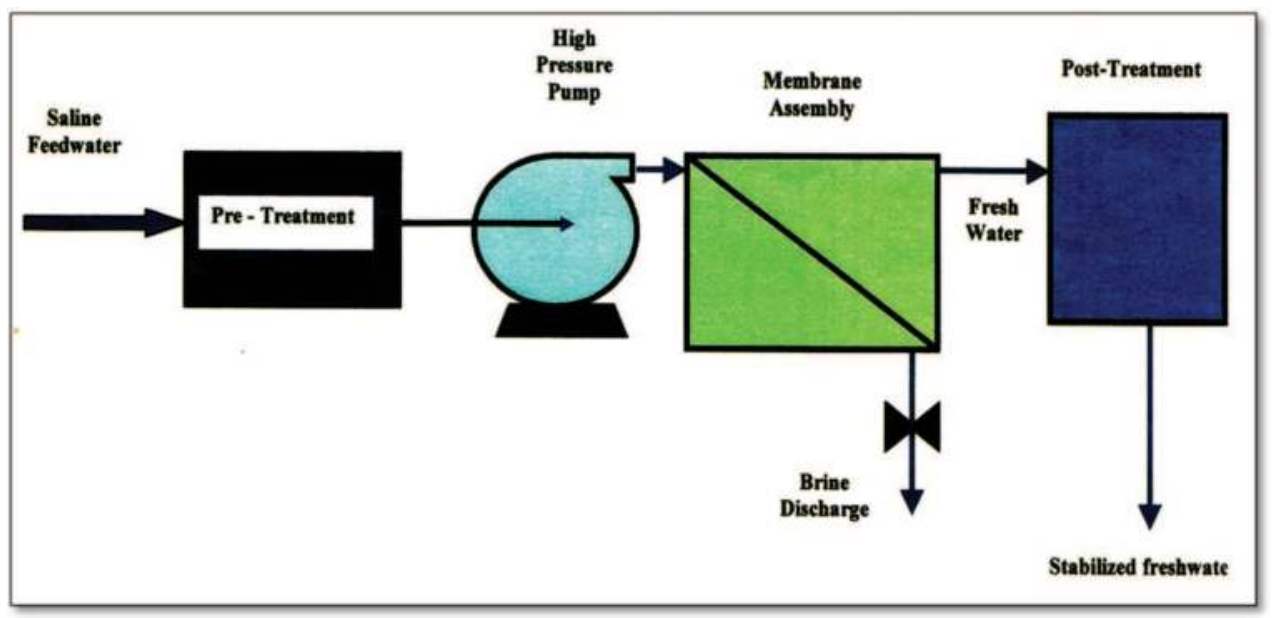

Fig. 2. Flow diagram of $\mathrm{RO}$ desalination process

\section{Desalination equipment}

To maintain this continuous and effective operation, a diversified assembly of equipment is employed in DPs including significant quantities of storage tanks, pumps, heat exchangers, pipes of varying sizes for both operational processes and transmission lines. Table 4 presents the varied equipment utilized in different DPs, both thermal distillation and membrane processes. Electric steam generators, made of SS UNS S30400 or S31600, are ideal for clean steam, reducing steam contamination introduced by steam piping. To improve boiler efficiency, an electrical conductivity sensor is utilized to determine steam conductivity in the range of 0 to $10 \mathrm{mS} / \mathrm{cm}$.

Reactive piping materials such as plain carbon steel, galvanized or cadmium plated steel and cast iron should not be used in DP's due to risk or corrosion and consequent contamination by corrosion products (Malik, 2001).

Flash evaporators, low pressure turbines, evaporators and condensers, operated in contact with steam, are particularly prone to corrosion by salts. Corrosion inhibitors are applied to avoid or minimize corrosion of steel, and other alloys provoked by corrosive impurities from steam or water such as chlorides, caustic, inorganic and organic acids, carbonates, sulphates, hydrogen sulphide and their mixtures (Table 4). 


\begin{tabular}{|l|l|}
\hline \multicolumn{1}{|c|}{ Pipes, tubes and ducts } & \multicolumn{1}{c|}{ Evaporators } \\
\hline Saline water pumps, vertical and centrifugal & Vapor condensers, Diesel engines \\
\hline Valves, diverse types & Flash chambers \\
\hline Gasketed plate-and-frame heat exchanger & Demisters \\
\hline Filters, diverse types & Steam generators \\
\hline Fittings and flanges & Condensers \\
\hline Steam and gas turbines & Dearators \\
\hline Compressors & Chlorinators \\
\hline Control and flow instrumentation & Storage tanks \\
\hline
\end{tabular}

Table 4. Equipment for desalination plants.

\section{Corrosion resistant alloys}

The varied equipment of DP is fabricated from a wide spectrum of engineering materials, metallic and non metallic, which display a reasonable endurance to the fluids (liquids, vapor and gases) handled and processed in the plant installations and environments.

The prime consideration during the selection of materials of construction is their corrosion characteristics. CRAs used in the desalination industry are classified into two large groups:

- $\quad \mathrm{Ni}$ - containing alloys e.g. Ni-base alloys, Cu-base alloys and SS.

- Titanium and aluminum alloys. e.g. UNS A95052

Their UNS (Unified Numbering System) designation and chemical composition are displayed in Table 5. In addition, nonmetallic materials such as plastics: polyethylene (PE), polypropilene (PP), polyvinylchloride (PVC) and composites, in particular fiber reinforced plastic (FRP) based on polyester and/or epoxy resins are employed mainly for piping and storage vessels.

Those CRAs have an outstanding corrosion resistance, mechanical strength and weldability. This corrosion resistance is due to the tenacious, durable and self-healing, protective film of metal oxides formed in the presence of air and moisture. According to ASTM standard D 4194, SS UNS S31600 should be used for all wetted parts of RO devices. Furthermore, it warns about the use of piping made of carbon steel, cast iron and galvanized or cadmium plated carbon steel to avoid contamination by corrosion products. Two most popular austenitic SS S30400 and S31600, several superaustenitics and duplex are in service in DPs, in seawater and brackish water applications, as material of construction for centrifugal pumps. In recent years, grades of SS with high resistance to pitting and crevice corrosion in seawater have been developed, e.g. the 6 Moly families of alloys with increased nitrogen content (Table 4). The CRAs industry employs advanced equipment and facilities, highly skilled engineering staffs and sophisticated quality control procedures, to develop and to produce suitable alloys for industrial applications. CRAs producers provide engineering and development services to Original Equipment Manufacturers (OEMs) to ensure their suitability to the DPs processes and fluids.

\subsection{Steel}

Carbon steel is the main material for the erection of plant structures, water storage, tanks and pipelines. Because of its useful mechanical properties, easy of machining and welding 
as low cost, it is preferred. But due to its limited corrosion resistance it should be protected by paints and coatings and in many structures in contact with water by cathodic protection. SS are iron-based alloys containing $\mathrm{Cr}$ as the main alloying element at a concentration of at least $12 \%$. They have outstanding corrosion resistance, mechanical strength and weldability; their corrosion resistance is due to the tenacious, durable and self-healing protective film of Chroming oxide (of 5 nanometer thickness) formed in the presence of air and moisture Unfortunately, this passive film can break down in SW containing chlorides, but it is enhanced when the SS contains Mo. Table 4 presents a great variety of SS applied in DPs around the world.

\section{$5.2 \mathrm{Ni}$-base alloys}

$\mathrm{Ni}$ - alloys are among the most important because they resist corrosion in a wide variety of environments, including SW rich in chlorides (Table 5). They are divided in two groups: those constituted mainly by $\mathrm{Ni}$ and those which employ $\mathrm{Cr}$ as a major alloying element. Their corrosion resistance depends upon the presence of Nickel and Chromium oxides imparting a passive state. They are used in DPs for the fabrication of high-pressure pumps and brine concentrators in thermal DPs.

\subsection{Copper-base alloys}

The main alloys used in DPs are: $\mathrm{Cu}-\mathrm{Ni}$ for tube and shell-heat exchangers and condensers (Table 5); bronze (Cu-Sn) for ship propellers and parts of pumps for seawater transportation and brass $(\mathrm{Cu}-\mathrm{Zn})$ for hot and cold water circulation. The blue, green layer of corrosion products which form on the $\mathrm{Cu}$-alloys surface does not provide effective protection.

\subsection{Titanium and aluminum alloys}

Ti has good corrosion resistance in strongly oxidizing environments, e.g. nitric acid and wet chlorine but not with reducing acids, e.g. hydrochloric acid. It can be readly shaped and formed; is available in conventional forms. Ti shows excellent resistance to seawater and SW but it does not tolerate even trace amounts of fluorides which cause severe corrosion. Its corrosion resistance is due to a stable, protective, strongly adherent film of titanium oxide $\left(\mathrm{TiO}_{2}\right)$. Alloying of $\mathrm{Ti}$ with palladium $(\mathrm{Pd})$ and other noble metals yields corrosion resistant alloys (Table 5).

Aluminum (Al) corrodes under both acidic and alkaline conditions yielding $\mathrm{Al}^{+3}$ and $\mathrm{AlO}_{2}{ }^{-}$ aluminates ions, respectively. When $\mathrm{Cl}^{-}$penetrates the passive film of $\mathrm{Al}_{2} \mathrm{O}_{3}$, it initiates pitting and crevice corrosion at localized sites with breakdown of passivity. The $\mathrm{Al}$ potential, about -1.65 volts (SHE) indicates its natural tendency to corrode but the oxide film imparts corrosion resistance to $\mathrm{Al}$ equipment in contact with SW, including seawater. In thermal desalination equipment $\mathrm{Al}$ tubes are utilized in huge heat-exchangers for condensation of water vapor with seawater.

\section{Corrosion, scaling and fouling}

Frequently, corrosion, scaling and fouling phenomena appear simultaneously in DPs; they interact and influence each other. Scaling and fouling have marked effect on corrosion, often associated with SW velocities. They originate in the SW, depending on their chemical and biological composition, their interaction with the equipment surface and plant operational conditions such as $\mathrm{pH}$, flow regime, temperature and pressure (The Newsletter, 2003). 


\begin{tabular}{|c|c|c|c|c|c|c|c|c|}
\hline \multirow[t]{2}{*}{ UNS* Number } & \multicolumn{8}{|c|}{ Chemical composition $\%$} \\
\hline & $\mathrm{Cr}$ & $\mathrm{Ni}$ & Mo & $\mathrm{Al}$ & $\mathrm{Cu}$ & $\mathrm{Ti}$ & C max. & Other \\
\hline \multicolumn{9}{|l|}{$\begin{array}{l}\text { Aluminium } \\
\text { alloys }\end{array}$} \\
\hline A95052 & & & & Bal. & & & & $2.5 \mathrm{Mg}, 0.25 \mathrm{Cr}$ \\
\hline A95054 & & & & Bal. & & & & $2.7 \mathrm{Mg}, 0.8 \mathrm{Mn}$ \\
\hline $\begin{array}{l}\text { Copper alloys } \\
\text { C70600 } \\
\text { C71900 }\end{array}$ & & $\begin{array}{l}10 \\
30\end{array}$ & & & $\begin{array}{l}90 \\
70\end{array}$ & & & $\begin{array}{l}1.0 \mathrm{Zn} \\
2.6 \mathrm{Cr}\end{array}$ \\
\hline \multicolumn{9}{|l|}{ Stainless steels } \\
\hline \multicolumn{9}{|c|}{ Austenitic chromium-nickel steels } \\
\hline S30400 & $18-20$ & $8-12$ & & & & & 0.08 & \\
\hline S30403 & $18-20$ & $8-12$ & & & & & 0.03 & \\
\hline S30908 & $22-24$ & $12-15$ & & & & & 0.08 & \\
\hline S31600 & $16-18$ & $10-14$ & $2-3$ & & & & 0.10 & \\
\hline S31603 & $16-18$ & $10-14$ & $2-3$ & & & & 0.03 & \\
\hline S31700 & $18-20$ & $11-14$ & $3-4$ & & & & 0.08 & \\
\hline \multicolumn{9}{|c|}{ High-alloyed austenitic } \\
\hline S31254 & 20 & 18 & 6.1 & & & & 0.02 & $0.2 \mathrm{~N}$ \\
\hline S32654 & 24 & 22 & 7.3 & & & & 0.015 & $0.5 \mathrm{~N}$ \\
\hline N08367 & 20.5 & 24 & 6.3 & & & & 0.03 & $0.22 \mathrm{~N}$ \\
\hline N08904 & 20 & 25 & 4.5 & & & & 0.02 & $1.5 \mathrm{Cu}$ \\
\hline N08926 & 20 & 25 & 6.8 & & & & 0.02 & $0.2 \mathrm{~N}, 1.0 \mathrm{Cu}$ \\
\hline N08020 & 21 & 25 & 4.5 & & & & 0.03 & $0.03 \mathrm{Cb}$ \\
\hline N08028 & 27 & 31 & 3.1 & & & & 0.02 & $1 . .0 \mathrm{Cu}$ \\
\hline N08031 & 27 & 31 & 6.5 & & & & & $0.2 \mathrm{~N}$ \\
\hline N08932 & 20 & 25 & 4.8 & & & & 0.01 & $0.2 \mathrm{~N}, 1.5 \mathrm{Cu}$ \\
\hline \multicolumn{9}{|c|}{ Austenitic, castings } \\
\hline J92500 & 19 & 10 & & & & & 0.03 & \\
\hline J92800 & 19 & 11 & 2.5 & & & & 0.03 & $0.2 \mathrm{~N}$ \\
\hline $\mathrm{J} 95150$ & 20 & 29 & 2.5 & & & & 0.07 & $3.5 \mathrm{Cu}$ \\
\hline \multicolumn{9}{|c|}{ Duplex: ferritic-austenitic } \\
\hline S32250 & 25 & 6.5 & 3.0 & & & & 0.02 & $0.17 \mathrm{~N}, 1.5 \mathrm{Cu}$ \\
\hline S31803 & 22 & 5.0 & 3.0 & & & & 0.03 & $0.15 \mathrm{~N}$ \\
\hline \multicolumn{9}{|l|}{ Ni-Base alloys } \\
\hline N06600 & 16 & Bal. & & & & & 0.08 & $8.0 \mathrm{Fe}$ \\
\hline N08825 & 21 & Bal. & & & & & & $29 \mathrm{Fe}, 2.0 \mathrm{Cu}$ \\
\hline N06030 & 30 & Bal. & 5.5 & & & & & $15 \mathrm{Fe}, 2.0 \mathrm{Cu}$ \\
\hline \multicolumn{9}{|l|}{ Titanium } \\
\hline R50250 & & & & & & 99.8 & 0.10 & \\
\hline R50450 & & & & & & 99.8 & 0.10 & \\
\hline R52400 & & & & & & Bal. & 0.10 & $0.15 \mathrm{Pd}$ \\
\hline
\end{tabular}

*UNS: Unified Numbering System

Table 5. CRAs used for manufacture of equipment in desalination plants 
Unless prevented, corrosion and the buildup of scale and biological fouling impact on the DP operation and in extreme cases even lead to equipment shutdown. Given the huge number of heat exchangers, condensers, pumps that handle SW; corrosion, and scale inhibitors and biocides should be applied as needed.

Pollution and corrosion are interrelated processes since many atmospheric pollutants, e.g. $\mathrm{SOx}, \mathrm{NOx}, \mathrm{COx}, \mathrm{H}_{2} \mathrm{~S}$ accelerate corrosion, and corrosion products such as rust also pollute water bodies. Both: pollution and corrosion are pernicious processes which impact the environment quality and the structures durability, particularity in coastal areas, near large cities and commercial-industrial ports contaminated with municipal, industrial and agricultural effluents (Schorr \& Valdez, 2005; Wiener et. al., 2006). As a result of these effluents, coastal pollution has reached crisis levels in many areas due to population growth, poor planning of land used in exaggerated development of tourism and its coastal facilities (Rasoanandrasana, 2010).

The $\mathrm{pH}$ values of $\mathrm{SW}$ are in the range of 5 to 8 and the concentration of dissolved oxygen (DO), the main corrodent, varies from 4 to $6 \mathrm{mg} / 1$ as a function of temperature and flow regime. SW contaminated with $\mathrm{H}_{2} \mathrm{~S}$, a reductant, are slightly acidic and corrosive towards some CRAs, therefore $\mathrm{H}_{2} \mathrm{~S}$ should be eliminated by mechanical or chemical methods.

\subsection{Corrosion}

Corrosion is an electrochemical process that takes place upon the metallic surface by reaction with the components of the SW. The dominant factors are DO concentration, temperatures and salinity. The overall corrosion process is the combination of two reactions: anodic and cathodic, that takes place at the metal-SW interface. For Fe the reaction is:

$$
2 \mathrm{Fe} \rightarrow 2 \mathrm{Fe}^{+2}+4 \mathrm{e}^{-}
$$

The cathodic reaction involves the reduction of DO:

$$
\mathrm{O}_{2}+2 \mathrm{H}_{2} \mathrm{O}+4 \mathrm{e}^{-} \rightarrow 4 \mathrm{OH}^{-}
$$

The overall corrosion reaction is:

$$
2 \mathrm{Fe}+\mathrm{O}_{2}+2 \mathrm{H}_{2} \mathrm{O} \rightarrow 2 \mathrm{Fe}(\mathrm{OH})_{2}
$$

Ferrous hydroxide $\mathrm{Fe}(\mathrm{OH})_{2}$ will further oxidize to ferric hydroxide $\mathrm{Fe}(\mathrm{OH})_{3}$ and eventually turn to rust $\left(\mathrm{Fe}_{2} \mathrm{O}_{3} \cdot \mathrm{xH}_{2} \mathrm{O}\right)$.

Corrosion inhibitors that slow down either the anodic or cathodic reactions or both, by interaction with corrosive ions, or form a protective film on the metallic surface, will reduce the extent of corrosion.

On the basis of the appearance of corrosion phenomena on the metal surface or in the geometry of the equipment, corrosion is classified as uniform when the metal corrodes at the same rate resulting in a uniform decrease of thickness or localized when corrosion appears at a specific area in a part of the equipment. Corrosion results from differences in aeration, concentration, $\mathrm{pH}$, water velocity. Types of localized corrosion which are often encountered in DPs, are illustrated in Figure 3.

Atmospheric corrosion in DPs installed in coastal zones is driven by the effect of marine aerosols containing humid particles of $\mathrm{NaCl}$. It is promoted by the formation of moisture 


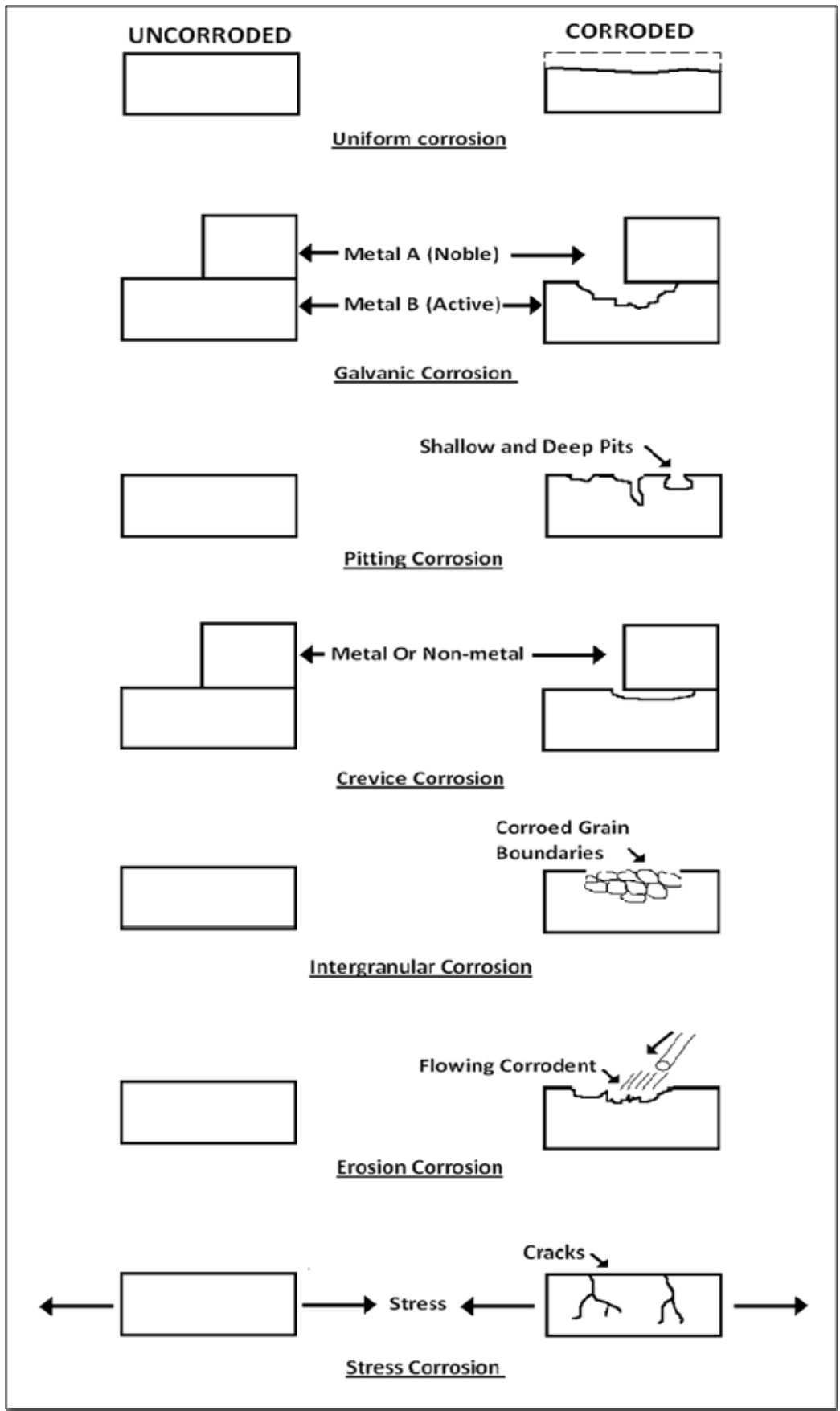

Fig. 3. Types of corrosion in desalination plants. 
layers on metal surfaces and by the chemistry of these layers .Climate change could influence the macro- and micro-surface effects controlling either the chemistry or the duration of these wet surfaces (Cole, 2010). Furthermore, hygroscopic salts absorb moisture and form deliquescent salt particles which can greatly accelerate the corrosion of metals $(\mathrm{Li}$, 2010). Corrosion damage increases maintenance expenses and generate problems in DP operation. In a recent report, (Koch, 2002) it was estimated that cost of corrosion in the USA is 276 billion USD on an annual basis, which represents $3.1 \%$ of the USA Gross Domestic Product (GDP), including 36 billion USD corrosion in drinking water and sewage systems.

\subsection{Scaling}

Highly concentrated SW tends to form thick scales by deposition of dissolved and suspended solid such as carbonates, silicates and hydroxides. As SW is circulated the last compound that tends to come out of the water is calcium carbonate. To prevent $\mathrm{CaCO}_{3}$ scaling the feed water is treated with sulfuric acid converting the carbonate to carbon dioxide $\mathrm{CO}_{2}$ that escapes from the water. When phosphates and phosphonates are applied to provide corrosion protection, careful control is implemented to avoid scaling by calcium phosphate $\left[\mathrm{Ca}_{3}(\mathrm{PO} 4)_{2}\right]$ adding organic polymers containing carboxilic acids for control of calcium phosphate deposition.

Chemical and physical pre-treatment of feed water is required to remove substances that would interfere with the desalting operation and will damage the equipment, in particular, the plastic membranes of the RO process. Pretreatment with ozone, a powerful oxidant and biocide will remove sulphur, iron, manganese and other water-soluble heavy metals compounds, bacteria, odor and color.

Some alkaline chemicals e.g. soda ash neutralize the acidity found in some brackish waters, helps reduce corrosion and extends the life of equipment. Citric acid removes iron and polyphosphates reduce iron staining but these pretreatments are rather expensive.

Scaling is controlled by introducing additives to inhibit crystal growth, reducing temperatures and salt concentration. Inorganic, colloidal particles, e.g. silica or silicic acid, hydrous iron oxide, aluminum oxide and organic substances in the feed water by special pretreatments. Furthermore, a particular type of corrosion, known as microbiologically influenced corrosion (MIC) develops under these complex organic and inorganic deposits. Chelating agents and acid are injected into the feed water to prevent precipitation and scaling on the RO membrane surface. Some DPs combine distillation with RO to produce both power and water.

\subsection{Fouling}

By their very nature SWs provide and ideal environment for macro- and micro- organisms to thrive. Unless properly controlled through the use of biocides; bacteria, algae, fungi, mollusk will grow on metallic surfaces. These organisms secrete polymeric substances, forming a film that generates acids and other harmful compounds that induce corrosion. Furthermore, they deplete and establish oxygen concentration cells causing localized and pitting corrosion. Many biocides are applied to prevent the formation of biological fouling; such as gaseous chlorine $\left(\mathrm{Cl}_{2}\right)$ sodium hypochlorite $(\mathrm{NaOCl})$, chlorine dioxide $\left(\mathrm{ClO}_{2}\right)$ and 
bromide salt $(\mathrm{NaBr})$. These chemicals should be used with appropriate regulations approval to avoid the proliferation of toxic agents.

The CRAs desalination equipment should be maintained clean and smooth to avoid calcareous scaling on heat transfer surfaces and to diminish the propensity to biological fouling on rough or polished surfaces. Acidic and alkaline cleaning is a mechano-chemical operation easily implemented in CRA equipment, to remove biological fouling and mineral scale since they alter the equipment surface performance and induce corrosion.

\section{Corrosion protection, monitoring and control}

Corrosion engineering and technology develop and apply methods and techniques of prevention and protection to avoid the interaction of the equipment and its construction materials with the corrosive factors of the DPs environment. Practical methods that minimize or eliminate corrosion include selection of suitable CRAs (Encyclopedia of Desalination, 2010; Habib, 2004; Malik, 2004) application of coatings, paints and linings to carbon steel and galvanized steel equipment and cathodic protection.

The technical process of selection is usually divided in to three main stages:

- Analysis of the requirements and collection of the relevant information about the conditions imposed by the desalination process and the corrosion resistance required by the equipment.

- Selection and evaluation of candidate materials by screening of the information collected in the first stage. Laboratory and pilot plant corrosion tests are performed by exposing suitable materials in the desalination process fluids and environments (ISO 845 and ASTM G4, G31).

- Selection of the most appropriate material based on its costs, availability, easy fabrication and repair, maintenance and safety.

Corrosion resistance is the main property to be considered in the choice of materials for DPs equipment but the final selection must be a compromise between technological and economic factors. It is sometimes more economical to use a high-priced CRA that will provide long and trouble-free service than to use a lower priced material that may require frequent maintenance or replacement. The selected CRA should be able to perform its function safely for a reasonable period of time and at a reasonable cost.

Corrosion monitoring $(\mathrm{CM})$ is the practice of measuring the corrosion events and rate by continuously exposing materials probes in a body of water or a operating DP. Modern electrochemical, electronic, mechanical, non-destructive and computational devices are applied in the field of $\mathrm{CM}$ such as potenciometry, multielectrode probes, electrical resistance, communication networks, remote $\mathrm{CM}$, expert programs and artificial neural networks. $\mathrm{CM}$ techniques provide daily warning of costly corrosion damage and critical information, where the damaging event is occurring and about the rate of deterioration. This information is essential to take decisions about the type, urgency and cost of preventive and curative measures to be applied on site without delay. (Robenge, 2000).

Chloride ion $\left(\mathrm{Cl}^{-}\right)$, a main component of SW, can breakdown the passive film of CRAs. Table 6 shows the upper limit of $\mathrm{Cl}^{-}$to assure corrosion resistant performance and how their increment in $\mathrm{Cr}, \mathrm{Ni}$ and Mo content enhances resistance to pitting and crevice corrosion. This graphic display might serve as a guideline for selection of SS and Ni-base 
alloys for desalination equipment handling brackish water with varied $\mathrm{Cl}^{-}$content (Valdez \& Schorr, 2000).

Today, the main and fastest source of information on corrosion control of industrial equipment, plants and facilities is the Internet. Data bases and computers based expert systems dealing with selection of materials, their properties and corrosion control for many environments and industries are listed in Roberge's Handbook (Roberge, 1999).

Important professional institutions dealing with corrosion research and control are the European Federation of Corrosion (EFC), NACE (National Association of Corrosion Engineers, USA), National Institute of Standards and Technology (NTIS), Materials Technology Institute (MTI), and other materials entities surveying the different computerassisted programs for corrosion control in industrial facilities. Other software is based on Artificial Neuronal Network (ANN) for the prediction, analysis and solving corrosion problems (Roberge, 1999). All these data-base expert systems and software are applicable for the plants, equipment installations and environments of the desalination industry.

Additional sources of corrosion information appear in data collections, handbooks and standards, in particular those published by the International Organization of Standardization (ISO); the American Society for Testing and Materials (ASTM), NACE International, USA, etc, (Mattsson,1996).

\begin{tabular}{|c|c|}
\hline $\mathrm{Cl}, \mathrm{pm}$ & CRAs \\
\hline \multirow{2}{*}{2000} & $\mathrm{~N} 06625$ \\
& $\mathrm{~S} 31803$ \\
\hline & $\mathrm{N} 06007$ \\
\hline & $\mathrm{S} 31254$ \\
\hline 1500 & $\mathrm{~N} 08904$ \\
\hline & $\mathrm{S} 31700$ \\
\hline 0 & $\mathrm{~S} 31600$ \\
\hline
\end{tabular}

Table 6. $\mathrm{Cl}^{-}$content in brackish water for corrosion resistance of CRAs.

\section{Closure}

In recent years, desalination experts have been playing an increasingly active role by refining desalination process, saving energy resources, selecting long-lasting CRAs and improving the efficiency of DPs. The worldwide increase in population, rising standards of living and the extension of water pollution evolves into a critical demand of potable water. Desalination technology is the obvious response to this challenge, to provide the water supply needed for the future generations.

\section{References}

Barlow, M and Clark, T. (2002). in Blue Gold, New Press, New York, 2002. 
Charach, J.; Schorr, M. \& et al. (1991). Corrosion and Scaling Behavior in Dead Sea Basin Saline Waters. Corrosion Reviews, Vol. 9, no 3-4, 1991.

Dillon, C.P.(1994). Corrosion Control in the Chemical Process Industries. Materials Technology Institute, ISBN: A-8779914-58-4.

Encyclopedia of Desalination and Water Reuse. (2010). Materials Selection and Corrosion, www.desware.net

Habib, K. et al (2001). Risk Assessment and Evaluation of Materials Commonly Used in Desalination Plants, Desalination 139, pp. 249-253.

I.D.E. Technologies. (2004), Fresh Water from the Sea, Israel, www.ide-tech.com

I.S. Paterson, D.A. (2010). Possible effects of climate change on atmospheric corrosion in Australia. Corr. Eng. Sci. and Tech, Vol.45(1) pp 19-26.

ISO 11845. (1995). Corrosion of metals and alloys, general materials for corrosion testing.

Koch G.H. et (2002). Corrosion Costs and Preventive Strategies in the USA. Supplement to Materials Performance. July, 2002. Also: www.corrosioncosts.com

Kowitt, B. (2009). The future of water. Fortune, pp 111-116. October 12, 2009.

Kronenberg, G. (2004). Ashkelon 100 MC/year, V.I.D Desalination Company Ltd, International Conference on Desalination Costing, Cyprus, December 2004.

Li, S.X. Hihara, L.H. (2010). Atmospheric corrosion initiation on steel from predeposition of $\mathrm{NaCl}$ particles in high humidity atmospheres. Corr. Eng. Sci. and Tech. Vol.45(1) pp 49-56.

Matteson, E. (1996), Basic Corrosion Technology for recientest and engineers, 2nd. Ed. The Institute of Materials, ISBN 86125 0118, London.

Malik, A.U. (2001) Case histories on the failure of pipelines in desalination plants, Saline Water Conversion Corporation, Saudi Arabia.

Miller, J. (2003). Review of Water Resources and Desalination Technologies. Materials Chemistry, Department Sandia National Laboratories SAND 2003-0800. http://www.sandia.gov/water/docs/MillerSAND2003_0800.pdf

Albuquerque, NM 87185-1349 P.A Roberge (2000), Handbook of Corrosion Engineering, Mc Graw Hill.

Roberge, P.R. (2010) Impact of climate change on corrosion risks, ditto.

Shiklomanov, I.A. (1993). Water in Crisis: A Guide to the World's Fresh Water Resources, P.H. Gleick, ed. Oxford University Press, New York, 1993

Schorr, M; Valdez, B. (2005), Corrosion of the marine infrastructure in polluted seaports, Corr. Eng. Sci and Tech. Vol 40.

The Newsletter,(2003), Critical Assessment of Fouling and Scaling Indices, Middle East Desalination Research Center, Oman, September 2003.

Valdez, B.; Schorr, M; et al. (2010). Effect of climate change on the durability of engineering materials in hydraulic infrastructure; an overview. Corrosion Engineering Source and Technology, Vol 45(1), pp.34-41/155 and 1478.

Valdez, B.; Schorr, M. (2010), Editors, Special Issue: Relationship of corrosion with climate change. Corr. Eng. Sci. Tech. Vol 45(1).

Valdez B.; Schorr, M. (2000). Stainless steel for corrosion control in desalination plants. Stainless Steel World, May, pp 40-44. 
Wiener, M.S.; Valdez, B.; et al. (2006). Effect of $\mathrm{H}_{2} \mathrm{~S}$ in corrosion in polluted water. Corr. Eng. Sci. Technical, Vol. 41(3) pp 221-227.

Zhw, X.R., Huang, L.Y. Lim, L.Y., Lim, D.Y. (2008). Corr. Eng. Sci. Tech. Vol 43(4), pp 328-334. 


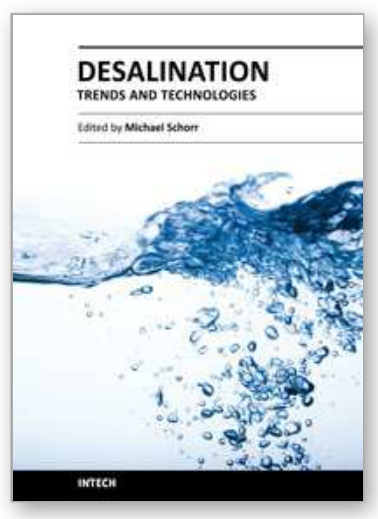

\author{
Desalination, Trends and Technologies \\ Edited by Michael Schorr
}

ISBN 978-953-307-311-8

Hard cover, 334 pages

Publisher InTech

Published online 28, February, 2011

Published in print edition February, 2011

The book comprises 14 chapters covering all the issues related to water desalination. These chapters emphasize the relationship between problems encountered with the use of feed water, the processes developed to address them, the operation of the required plants and solutions actually implemented. This compendium will assist designers, engineers and investigators to select the process and plant configuration that are most appropriate for the particular feed water to be used, for the geographic region considered, as well as for the characteristics required of the treated water produced. This survey offers a comprehensive, hierarchical and logical assessment of the entire desalination industry. It starts with the worldwide scarcity of water and energy, continues with the thermal - and membrane-based processes and, finally, presents the design and operation of large and small desalination plants. As such, it covers all the scientific, technological and economical aspects of this critical industry, not disregarding its environmental and social points of view. One of InTech's books has received widespread praise across a number of key publications. Desalination, Trends and Technologies (Ed. Schorr, M. 2011) has been reviewed in Corrosion Engineering, Science \& Technology - the official magazine for the Institute of Materials, Minerals \& Mining, and Taylor \& Francis's Desalination Publications. Praised for its "multi-faceted content [which] contributes to enrich it," and described as "an essential companion...[that] enables the reader to gain a deeper understanding of the desalination industry," this book is testament to the quality improvements we have been striving towards over the last twelve months.

\title{
How to reference
}

In order to correctly reference this scholarly work, feel free to copy and paste the following:

Michael Schorr, Benjamin Valdez, Juan Ocampo and Amir Eliezer (2011). Corrosion Control in the Desalination Industry, Desalination, Trends and Technologies, Michael Schorr (Ed.), ISBN: 978-953-307-3118, InTech, Available from: http://www.intechopen.com/books/desalination-trends-and-technologies/corrosioncontrol-in-the-desalination-industry

\section{INTECH}

open science | open minds

\section{InTech Europe}

University Campus STeP Ri

Slavka Krautzeka 83/A

51000 Rijeka, Croatia

\section{InTech China}

Unit 405, Office Block, Hotel Equatorial Shanghai

No.65, Yan An Road (West), Shanghai, 200040, China

中国上海市延安西路 65 号上海国际贵都大饭店办公楼 405 单元 
Phone: +385 (51) 770447

Fax: +385 (51) 686166

www.intechopen.com
Phone: +86-21-62489820

Fax: +86-21-62489821 
(C) 2011 The Author(s). Licensee IntechOpen. This chapter is distributed under the terms of the Creative Commons Attribution-NonCommercialShareAlike-3.0 License, which permits use, distribution and reproduction for non-commercial purposes, provided the original is properly cited and derivative works building on this content are distributed under the same license. 